\title{
二酸化炭素排出抑制技術・システムのニュータウン建設への適用
}

\section{REDUCTION OF CARBON DIOXIDE EMISSION FROM CONSTRUCTION OF NEW TOWNS}

\author{
伊藤武美 ${ }^{*}$ 花木啓祐 ${ }^{*}$ 、 本多博 ${ }^{*}$ \\ Takemi ITO* ${ }^{*}$ Keisuke HANAKI ${ }^{*}$, Hiroshi HONDA**
}

\begin{abstract}
In order to evaluate the possibility of reduction of life cycle $\mathrm{CO}_{2}$ emission from an actual new habitation district, an advanced method of estimation was developed, by using combination of the process analysis and the input-output analysis on the amount of materials in the main. $\mathrm{CO}_{2}$ emission from the district in the construction and operating stage was estimated as 164 thousand ton-C during 15 -year period of use.

Several feasible alternatives were proposed to reduce $\mathrm{CO}_{2}$ emission there, and each improvement effect was estimated. $\mathrm{CO}_{2}$ emission from the civil construction will be reduced by $4.1 \%$ by adapting slope in place of brick or concrete wall, by $3.4 \%$ by changing materials of pedestrian pavement. $\mathrm{CO}_{2}$ emission during 15 -year period of use will be reduced by $4.5 \%$ by introducing photovoltaic power system, by $1.0 \%$ by introducing solar thermal system and by $2.3 \%$ by construction of district heating and cooling system. The cost of reduction ranged between -1.6 thousand yen $/ \mathrm{kg}-\mathrm{C}$ and 0.7 thousand yen $/ \mathrm{kg}-\mathrm{C}$.
\end{abstract}

KEYWORDS ; life cycle assessment(LCA), urban planning, carbon dioxide $\left(\mathrm{CO}_{2}\right)$ emission, photvoltaic power system(PV), solar thermal system, district heating and cooling system(DHC)

1.はじめに

近年の都市づくりに関しては、持続可能な開発の視点が重視されるようになり、事前に地球環境に及ほす

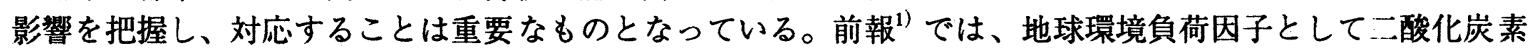
$\left(\mathrm{CO}_{2}\right)$ を選定し、具体的なニュータウンを対象に、造成工事を主に建設にともなう $\mathrm{CO}_{2}$ 排出量について推 計した。また、建設段階と運用段階を通じたライフサイクル的評価（LCA）を行い、CO2排出要因を整理し、 その抑制の考え方を提示した。

本研究では、まず、 $\mathrm{CO}_{2}$ 排出量についてより詳細に推計するために、前報 ${ }^{1)}$ で用いた金額に基づく $\mathrm{CO}_{2}$ 排 出量推計方法を改良し、物量主体の推計方法を用いた。

次に、ニュータウン建設にともなう $\mathrm{CO}_{2}$ 排出量を抑制するためには、プランナー、行政、住民、個別機器 等さまざまなレべルで対応する必要があり、なかでもプランニング時の配慮による抑制は重要と考えた。プ ランナーの意図が比較的反映可能で現実的に導入可能性のあるCO2排出量抑制方法として、(1)造成工事の範 囲内でほほ機能を損なわずに対応可能な方法、(2)供用時に利用制約が小さく、建売住宅等に組み込むことで 対応可能な方法、(3)マスタープランにおいて配虑することで都市環境インフラとして整備可能な方法の3方 法を挙げた。これらの削減方法について、Pニュータウンの設計を現実的に見直して、アメニティ面も勘案 しつつ検討し、建設時および供用時のCO2排出量の増減量を定量的に推計した。

さらに、 $\mathrm{CO}_{2}$ 排出量の抑制可能量および費用対効果の関係から各方法の特徴を明らかにし、プランナーが ニュータウン計画段階において対応可能な実践的な $\mathrm{CO}_{2}$ 排出抑制方法を整理した。

\section{2.解析対象と解析手法の概要}

2.1解析対象ニュータウンの概要

本研究ではライフサイクル的評価の対象として、宮城県において施工中のPニュータウンを選定した。Pニュー タウンは、トンネル・橋梁等の特殊工法を必要としない標準的な丘陵地形・地質を有し、面積約162ha、計 画人口9,600人、戸建住宅と集合住宅あわせて約2,400戸と近隣住区としてまとまった規模である。

*東京大学先端科学技術研究セン多 Research Center for Advanced Science and Technology,The University of Tokyo

**大成建設(株)開発本部計画部 Planning Dept.,Urban and Regional Development Div., TAISEI CORPORATION 
表1 主要土地利用計画面積および規模想定

$\mathrm{P}$ ニュータウンは、住宅用地と業務・商業施設用地 の複合開発であることから（表1参照）、低密度な郊 外型住宅地に導入可能な個別技術のみならず、通常 は高密度が求められる地域冷暖房等の都市環境イン フラ技術の導入可能性がある。これらの特徴により、 $\mathrm{P}$ ニュータウンは、他のニュータウン計画への援用可 能性が大きいと考え検討対象とした。

\section{2適用した解析手法}

財やシステムの波及効果を含めたエネルギー消費量 や環境負荷の分析方式には、大きく分けて(1)産業連

\begin{tabular}{|c|c|c|c|}
\hline 名 称 & 用地面積 & 延床面積 & 備 考 \\
\hline $\begin{array}{l}\text { 戸建住宅用地 } \\
\text { 集合住宅用地 } \\
\text { 業務施設用地 } \\
\text { 商業施設用地 } \\
\text { 栗務施設用地 }\end{array}$ & $\begin{array}{r}46.5 \mathrm{ha} \\
10.4 \mathrm{ha} \\
16.7 \mathrm{ha} \\
\mathrm{C}^{12.0 \mathrm{ha}} \\
\end{array}$ & $\begin{array}{r}14.9 \mathrm{ha} \\
8.9 \mathrm{ha} \\
5.5 \mathrm{ha} \\
2.1 \mathrm{ha} \\
2.0 \mathrm{ha}\end{array}$ & $\begin{array}{l}110 \mathrm{~m}^{2} / \text { 戸と想定 } \\
85 \mathrm{~m}^{2} / \text { 戸と想想定 } \\
\text { 計画案か想想 } \\
\text { 計画案から想 } \\
\text { 計画案から想 }\end{array}$ \\
\hline $\begin{array}{c}\text { 小学校用地 } \\
\text { 道路用地 } \\
\text { 公園用地 } \\
\text { 緑地 } \\
\text { その他 }\end{array}$ & $\begin{array}{r}3.9 \mathrm{ha} \\
28.6 \mathrm{ha} \\
10.3 \mathrm{ha} \\
19.5 \mathrm{ha} \\
13.6 \mathrm{ha}\end{array}$ & $\begin{array}{c}0.9 \text { ha } \\
-- \\
-- \\
- \\
-\end{array}$ & 5箇所 \\
\hline 合計 & $161.5 \mathrm{ha}$ & 34.3ha & 約60人/ha \\
\hline
\end{tabular}
関表方式、(2)個別積み上げ方式、(3)組み合わせ方式 の3種類がある。本研究では、具体的なニュータウン計画案を評価し、代替案の採用などの改善を行うため にエネルギー・物質代謝構造のようなシステム性のある対象の場合に利用できる(3)組み合わせ方式を選定 した。この方式は、積み上げ方式と同様に造成工事に使用する材料や現場での施工機械、消費燃料の数量を 求め、別途先行研究等で明らかにされている $\mathrm{CO}_{2}$ 排出強度を乗じて、 $\mathrm{CO}_{2}$ 排出量を推計する方式であり、前 報1) では金額のみに基づき推計したが、本研究では物量を主に推計して金額で補足する方法に改良した。こ のことにより、物価変動や人件費、個別の契約事情の影響を軽減でき、また、代替案との比較に際しても、 普及度の差異による価格差の影響等を除くことができる。 $\mathrm{CO} 2$ 排出強度については先行研究のなかでも作成方法 や値に差異があり、透明性と統一性を図るため、他の研 究との比較や今後の更新を考慮し広く認知されている建 設省総プロの検討値 ${ }^{2)}$ 、建築学会・空調衛生学会の検討 值 ${ }^{3}$ 等を引用した（表2参照）。

本研究では、物量当たり $\mathrm{CO}_{2}$ 排出強度および使用物量 の双方が明らかな項目については、物量ベースにより 推計した。その際、物量当たり $\mathrm{CO}_{2}$ 排出強度の全てにつ いて積み上げ方式により算定された值を入手すること は、他産業の多種多様な製品等を現場で組み合わせる 建設業の特性から難しい。そこで、まず、積み上げ方 式による物量当たり $\mathrm{CO}_{2}$ 排出強度 ${ }^{2)}$ を優先的に引用し、 次いで産業連関表の逆行列と物量表等から算定された 物量当たり $\mathrm{CO}_{2}$ 排出強度 ${ }^{3)}$ を引用した。

物量当たり $\mathrm{CO}_{2}$ 排出強度または使用物量のどちらかが 表2 主な $\mathrm{CO}_{2}$ 排出強度

\begin{tabular}{|c|c|c|}
\hline 項 目 & $\mathrm{CO} 2$ 排出強度 & 備 考 \\
\hline 軽油 & $0.788 \mathrm{~kg}-\mathrm{C} / \mathrm{l}$ & 産業連関表方式 ${ }^{3)}$ \\
\hline 電力 & $0.139 \mathrm{~kg}-\mathrm{C} / \mathrm{kWh}$ & 積み上げ方式" \\
\hline 都市ガス & $0.0721 \mathrm{~kg}-\mathrm{C} / \mathrm{Mcal}$ & 産業連関表方式 ${ }^{3)}$ \\
\hline セメント & $0.217 \mathrm{~kg}-\mathrm{C} / \mathrm{kg}$ & 積み上げ方式”を補正 \\
\hline 生コンクリート & $70.2 \mathrm{~kg}-\mathrm{C} / \mathrm{m}^{3}$ & 積み上げ方式"2を補正 \\
\hline コンクリートブロック & $0.0671 \mathrm{~kg}-\mathrm{C} / \mathrm{kg}$ & 積み上げ方式》を補正 \\
\hline レンガ & $0.0629 \mathrm{~kg}-\mathrm{C} / \mathrm{kg}$ & 積み上げ方式")を補正 \\
\hline 建設機械 & $0.817 \mathrm{~kg}-\mathrm{C} / 千 円$ & 産業連関表方式 ${ }^{3)}$ \\
\hline
\end{tabular}

*燃焼および石灰石起因部分,流通部分を含む 不明な項目については、補足的に、産業連関表による購 入額当たり $\mathrm{CO}_{2}$ 排出強度 ${ }^{3)}$ を用いて金額ベースにより推計することを併用した。

建設機械等の製造部分は、リース使用が多い実情にあわせて、製造時 $\mathrm{CO}_{2}$ 排出量と、耐用年数と年間標準 運転時問等から算定される時間当たり損料率等を用いて使用時間当たり CO2排出量を近似的に計上した。

本研究では、宮城県で使用する資機材の $\mathrm{CO}_{2}$ 排出強度に全国平均值を引用していること、また、 $\mathrm{CO}_{2}$ 排出 強度の根拠が統一できていないこと等の課題があるが、推計全体へ与える影響の大きな項目についてはでき るだけ物量ベースで推計し、相対的に影響の小さな項目は金額で簡便に扱い、項目の網羅性に配慮した。

\section{3.ニュー㚈ノ建設による $\mathrm{CO}_{2}$ 排出量の推計結果}

\section{1 二エ多方造成工事による $\mathrm{CO}_{2}$ 排出量の推計結果}

前述の推計手順により、Pニュータウン造成工事による $\mathrm{CO}_{2}$ 排出量を推計すると、約 27.2 千ton-Cとなった (表3参照)。このうち、物量ベースの推計による量は、約 20.4 千 ton-Cで約 $75 \%$ を占め、残りは金額ベース の推計により補足した部分である。工事額当り $\mathrm{CO}_{2}$ 排出量は $1.1 \mathrm{~kg}-\mathrm{C} /$ 千円、面積当りに換算すると $16.8 \mathrm{~kg}-\mathrm{C} / \mathrm{m}^{2}$ に相当する。公園以外のPニュータウン造成工事について、金額ベースのみにより推計した前報 1)の約 22.5 千ton-Cと比べると、約 $15 \%$ の差異であった。差異の生じた理由としては、資材等によっては購入 
単価が全国平均と異なることが挙げられる。

$\mathrm{CO}_{2}$ 排出量を項目別にみると、建設材料に起因 する割合が約 $52 \%$ と過半を占め、ブルドーザー、 バックホウ等の建設機械の運転用燃料による部分 は約 $37 \%$ 、建設機械の製造による部分は約 $11 \% を$ 占める（表3参照）。

建設材料の明細を分析すると、平板ブロック、 石積ブロック、セメント、生コンクリート等のセ メント製品による $\mathrm{CO}_{2}$ 排出量が大きい。工種別に みると、整地工、道路筑造工、㩲壁工等の $\mathrm{CO}_{2}$ 排 出量が大きい。

これらの解析から、造成工事による $\mathrm{CO}_{2}$ 排出量 を削減するためには、機能的に代替可能な範囲内 でセメント製品の使用量削減が重要とわかった。

$\mathrm{CO}_{2}$ を最も排出する整地工については、現況地 形を計画戸数の住宅地に造成するために不可欠で あり、代替方法がそしく、建設重機の燃費の向上 あるいは、革新的な土地利用計画に転換する等の 対応方法が必要と考えられる。

表3 造成工事からのCO2排出量 単位: ton-C

\begin{tabular}{|l|r|r|r|r|r|}
\hline \multicolumn{1}{|c|}{ 項目 } & 燃料 & 機械 & 材料 & 合計 & 割合) \\
\hline 防災工 & 717 & 225 & 479 & 1,422 & $5.2 \%$ \\
\hline 整地工 & 7,095 & 2,249 & 1 & 9,345 & $34.4 \%$ \\
\hline 法面工 & 135 & 34 & 272 & 441 & $1.6 \%$ \\
\hline 雨水排水工 & 468 & 93 & 1,577 & 2,138 & $7.9 \%$ \\
\hline 污水排水工 & 411 & 66 & 792 & 1,269 & $4.7 \%$ \\
\hline 道路築造工 & 264 & 83 & 3,325 & 3,672 & $13.5 \%$ \\
\hline 水道配管工 & 139 & 31 & 1,315 & 1,485 & $5.5 \%$ \\
\hline 歩道工 & 11 & 7 & 1,100 & 1,117 & $4.1 \%$ \\
\hline 街路灯設置 & 26 & 14 & 321 & 360 & $1.3 \%$ \\
\hline 交通安全 & 7 & 4 & 618 & 629 & $2.3 \%$ \\
\hline 集壁工 & 320 & 93 & 2,184 & 2,596 & $9.5 \%$ \\
\hline 宅地整備工 & 46 & 11 & 305 & 362 & $1.3 \%$ \\
\hline 付帯工 & 378 & 114 & 1,195 & 1,687 & $6.2 \%$ \\
\hline 公園工 & 72 & 21 & 588 & 681 & $2.5 \%$ \\
\hline 合計 & 10,089 & 3,044 & 14,072 & 27,205 & $100 \%$ \\
\hline (割合) & $37.1 \%$ & $11.2 \%$ & $51.7 \%$ & $100.0 \%$ & \\
\hline
\end{tabular}

\section{2ニュータヴンの建築・供用時を通した $\mathrm{CO}_{2}$ 排出量の推計結果}

ニュータウンは主に造成部分 (道路、上下水道等の都市 インフラ部分を含む）と住宅等の建築部分から構成される。 建築工事からのCO 2 排出量および都市活動・生活が営まれ る供用時についてのCO2排出量を概略推計した前報1) の結 果を示す。

$\mathrm{P}$ ニュータウン建築工事からの $\mathrm{CO}_{2}$ 排出量は約 43.7 千 ton-Cと推計され、造成工事からのCO2排出量の約1.6倍に 相当した。

供用時は建築関連の空調・給湯・照明等のエネルギー消 費量を想定し（図1参照）、CO2排出量を推計したところ、 約6.2千ton-C/年となった。ただし、上下水道、ごみ収集 · 処理による $\mathrm{CO}_{2}$ 排出量は合計してもエネルギー関連の $4.2 \%$ にすぎないため、今回の検討からは除外した。

比較的低密度な郊外型ニュータウン建設活動においても、 $\mathrm{CO}_{2}$ 排出量に関して建築工事の寄与する割合が大きく、ま た、造成と建築をあわせた建設時の約70.9千ton-Cは、供 用時の約 11 年分に相当した。

\section{CO2排出量の抑制可能量の推計}

$\mathrm{CO}_{2}$ 排出量の抑制に関してはプランナー、行政、住民、 個別機器等さまざまなレベルで対応する必要がある。しか し、個々の機器・設備やライフスタイル等による対応方法 は、抑制に寄与しうる余地は大きいが、これらは住民自身 の判断で行われる部分でありプランナーや行政の期待通り に実現できる担保はない。本研究ではプランニング時の配 慮による抑制が重要と考え、プランナーの意図が比較的反

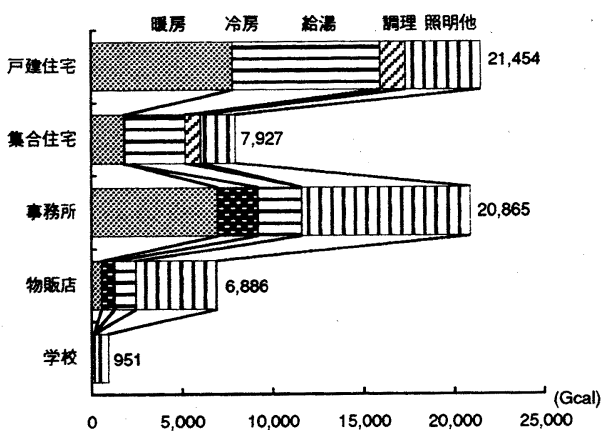

図1 供用時の建物関連工礼ギー消費量（年間）

表4 $\mathrm{CO}_{2}$ 排出量抑制方法一覧

\begin{tabular}{|c|c|}
\hline 項 目 & 備 考 \\
\hline 1-1ブロック擁壁の法面化 & 宅地廻り、 $\mathrm{H}=0 \sim 2 \mathrm{~m}$ \\
\hline 1-2RC擁壁の法面化 & 周辺部、 $\mathrm{H}=2.5 \sim 5.0 \mathrm{~m}$ \\
\hline 1-3歩道の舗装の変更 & 擬石平板をアスコンへ \\
\hline 1-3公園の仕様変更 & 街区公園、近隣公園 \\
\hline 2-1太陽光発電システム & 住宅および業務・商業 \\
\hline 2-2太陽熱温水器 & 戸建住宅のみ \\
\hline 3-1地域冷暖房システム & $\begin{array}{l}\text { 業務・商業の冷暖房給湯 } \\
\text { 集合住宅の給湯 }\end{array}$ \\
\hline 3-2土地利用計画変更 & 地域冷暖房システ対応 \\
\hline
\end{tabular}


く、建売住宅等に組み込むことで対応可能な方法、(3)計画時点で配慮することで都市環境インフラとして 整備可能な方法を検討した（表4参照）。

(1)造成工事関連の抑制方法は、最大のCO2排出要素のセメント関連製品に着目し、擁壁等のコンクリート 構造物や歩道舗装ブロックの見直し、公園の遊戯施設の整備コンセプトや仕様の変更等を検討した。もち ろん、機能面で完全に代替可能ではないが類似の機能と判断できる範囲のため意義があるとした。その他 の防災工事、上下水道工事等は必要不可欠かつ開発指導要綱等で定められているため改善の余地はそしい。

低密度な郊外型ニュータウンに個別に適用可能な $\mathrm{CO}_{2}$ 排出抑制技術は、パッシブ建築、太陽光発電システ ム、太陽熱利用システム、省エネ家電等に限られる。本研究では(2)供用時に利用制約が小さく、建売住宅、 建築条件付住宅地に組み达むことで対応可能な方法として、太陽光発電システムと太陽熱温水器システムを 検討対象に挙げた。また、(3)都市環境インフラとしては、地域冷暖房システムを検討した。通常は高密度 開発地区で導入されるシステムであるが、未利用エネルギー活用やスーパーヒートポンプ等の今後の技術革 新の余地が大きいため対象とした。さらに、低密度地区の場合には地域配管部分の排出負荷や費用負担が大 きいため、地域配管延長を削減できうる土地利用計画代替案も検討した。

それらの検討期間は、都市のような複合的なものの場合は個々に更新期間が異なり、また、本研究は導入 技術による比較検討を主題とするため、各施設がほほ耐用年数内で大規模な修繥・解体時期を迎える前が適 当と考えて 15 年間とした。3章に示した原案では、建設時と供用 15 年合計のCO2排出量は約 164.2 ton-Cとなる。

\section{1造成工事関連のCO2排出量の抑制}

（1）宅地廻りブロック積擁壁の法面化

住宅地まわりのブロック積擁壁は舗装面と宅地面高さの 差の調整のために設けられるもので、設計図書の確認に より、排出負荷の大きいコンクリートブロック擁壁（勾 配1：0.3）を排出負荷の小さい法面（勾配1：1.8）に置換 えることは技術的には可能とわかった（図2参照）。施工 歩掛等を原計画と同等として置換えた場合には、 $\mathrm{CO} 2$ 排出 量は1,900ton-C減少する（図3参照）。これは造成工事全 体のCO2排出量の $7.0 \%$ 削減に相当し、工事費も5.4\%削減 でき事業費全体が圧縮できる。

しかし、高さ $1 \mathrm{~m}$ の場合では、宅地内の平地部分が、勾 配の差とブロック笠石のために $1.2 \mathrm{~m}^{2} / \mathrm{m}$ 程度減少するため、 建物や庭の配置について居住者の自由度が減る短所があり、 合意を得づらい面がある。そこで、道路沿いの民地には、 協定緑地 $(\mathrm{W}=0.5 \mathrm{~m}-0.8 \mathrm{~m})$ が設けられていることに注目し、 法面部分も協定緑地として認めることとすれば、宅地内の2象:全て法面 減少分を緩和できる。地上高 $1 \mathrm{~m}$ 未満の擁壁を法面化する のであれば、工事費減少と平地部分の実質減少が金額的に はほほ同等となり、現実的な導入可能性が高まると期待で きる。その場合には、 $\mathrm{CO}_{2}$ 排出量は908ton-C減少し、造成 工事全体の $3.3 \%$ 、工事費は $2.6 \%$ 程度削减できる。その際、 緑化空間変更による景観への影響やプライバシー、防犯面 等を含めた配慮が必要である。

（2）RC擁壁の法面化

$\mathrm{CO}_{2}$ 排出負荷の極めて大きい鉄筋コンクリート（RC） 擁壁は、商業・文化施設と外周緑地の間の宅地面高さと自 然地形との調整のために設けられている。設計図書の確認 により、 $\mathrm{RC}$ 擁壁（H=2.5-5m,勾配1：0）を切土法面（勾配 $1: 1.5)$ に全て置き換えることは可能と判断できた。

施工歩掛等を原計画と同等として単純に置換えた場合に は、 $\mathrm{CO}_{2}$ 排出量は226ton-C減少し、これは造成工事の $0.8 \%$

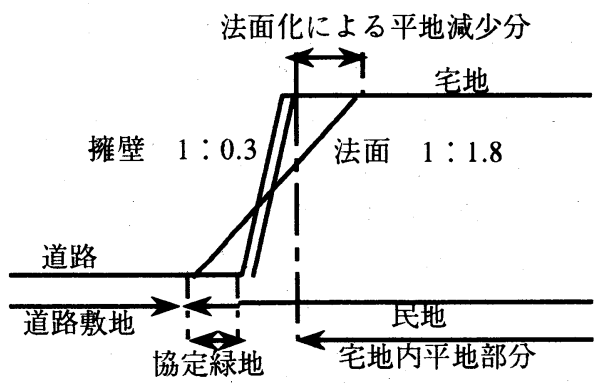

図2 ブロック積擁壁の法面化の断面イメージ

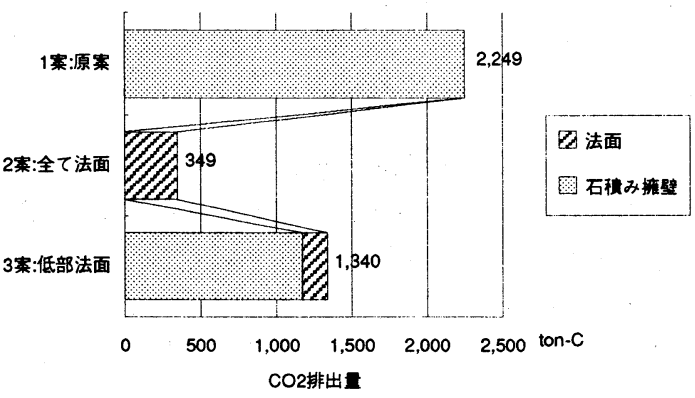

図3 ブロック積擁壁の法面化による $\mathrm{CO}_{2}$ 排出量 の比較

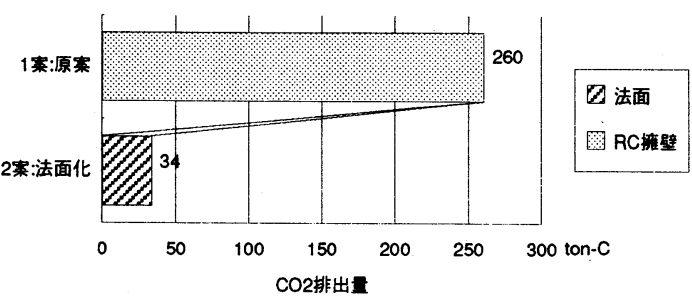

図4 RC擁壁の法面化による $\mathrm{CO}_{2}$ 排出量の比較 
に相当し（図4参照）、工事費は $0.8 \%$ 程度の削減となる。これは、面積当たり $\mathrm{CO}_{2}$ 排出量および工事単価は 法面の方がはるかに小さいが、法面化により施工面積が約10倍に増大するため、削減効果は小さくなるため である。逆に、法面化により自然緑地を $4,800 \mathrm{~m}^{2}$ 減少させることになるため、自然保護および樹木による $\mathrm{CO}_{2}$ 固定量を含めた考慮が必要である。

（3）歩道の平板舗装の見直し

道路築造工の中でも $\mathrm{CO}_{2}$ 排出量の大きいものは歩道部分 の稲田擬石等の平板ブロックであり、これを開粒度アスコ ンに変更することは技術的には容易である。

歩道を全てアスコン舗装にした場合には、 $\mathrm{CO}_{2}$ 排出量は 925ton-C減少し、これは造成工事の $3.4 \%$ に相当する。ま た、工事費は $2.3 \%$ 程度の削減となる。ただし、これは、 ニュータウンの景観や、グレード、アメニティにかかわる 内容であり、代替可能と判断できるかは議論の余地がある。 現害的には全てをアスコン舗装とせず、擬石平板舗装を要 所要所に残しつつ対応することが考えられる（図5参照）。

\section{（4）公園の仕様変更}

$\mathrm{P}$ ニュータウン内の街区公園4箇所、近隣公園1箇所の建

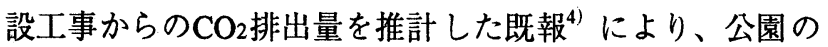
デザイン、遊具等の選定により単位面積当たり $\mathrm{CO}_{2}$ 排出量 に5〜40\%の差があることを把握した。

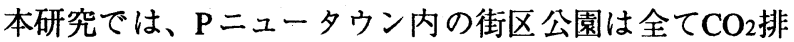
出量が最小の公園のデザイン、遊具等の選定を用いること とし、近隣公園についてはCO2排出量が大きい壁泉を修景 施設として設けない場合を想定した。

これらの場合には、CO2排出量は142ton-C減少し（図6参 照）、これは公園工事の $20.9 \%$ 、造成工事全体の $0.5 \%$ に 相当する。また、工事費は $0.8 \%$ 程度の削減となる。現実 的には画一的な公園デザインは好ましくないが、求められ る機能をふまえつつ、工事金額のみならず、 $\mathrm{CO}_{2}$ 排出量の 面でも配慮することが重要となる。

（5）造成工事関連まとめ

$\mathrm{P}$ ニュータウンの造成工事からのCO2排出量は以上の対 応方法の組合せにより、最大で3,190ton-C、現実的には 1,640ton-C程度の抑制が期待できる。これらは原計画の造 成工事から $11.7 \%$ 削減と6.0\%削減に相当する (図7参照)。

\section{2太陽エネルギー利用による $\mathrm{CO}_{2}$ 排出量の抑制}

\section{(1) 太陽光発電システム}

太陽光発電システムを戸建て住宅、集合住宅、事務所、学校の屋根に設置した場合を想定した前報 ${ }^{1)}$ の結 果を示す。個人住宅用太陽光発電システム $\left(3 \mathrm{kWp}, 30 \mathrm{~m}^{2}\right)$ の発電量は、メーカーカタログ5) から仙台地域の $244 \mathrm{kWh} /$ 月を引用し、他の用途向けも同性能と仮定した。設置面積は、政策的に強力に導入した場合を想定 し、戸建て住宅は各戸に $30 \mathrm{~m}^{2}(3 \mathrm{kWp})$ 相当の $40,700 \mathrm{~m}^{2}$ 、その他は、設置主体等の課題は考慮せずに単純に 屋根面積の $50 \%$ 相当の $16,660 \mathrm{~m}^{2}$ と仮定した。その場合の年間発電量は約 $5.6 \mathrm{GW} \mathrm{h} /$ 年と推計され、これは年間 電力消費量の約 $22 \%$ に相当する。

一方、太陽光発電システムの太陽電池パネル本体及び周辺機器、架台等を含めた製造時のCO2排出量は、 稲葉ら ${ }^{6)}$ の研究によるエネルギーペイバックタイム（EPT） 5.675年を引用し、約4.4千 ton-Cと推計した。 太陽光発電システムによる $\mathrm{CO}_{2}$ 排出量抑制効果は、未導入の原案と比べて、建設時では約4.4千 ton-C（土 
木および建築からのCO2排出量の $6.1 \%$ 相当）増加するが、 供用時では約 0.8 千ton-C/年（未導入時の $12.5 \%$ 相当）减少 し、建設から供用後 15 年間を通したCO2排出量は約 $4.5 \%$ 削 減可能となる（図8参照）。

太陽光発電システムの設置費用は、近年、低下傾向にあ る。国の補助も含めて 100 万円 $/ \mathrm{kWp}$ の場合、電力料金の節 減による初期費用回収期間は約42年となり、酎用年数以上 に相当し、未だ経済的には導入可能性は小さい（図9参照）。

\section{（2）太陽熱温水器}

検討ケースとして、太陽熱温水器を戸建て住宅の屋根に 直置設置し、架台不要の場合を想定した。

建設時のCO2排出量は、個人住宅用太陽熱温水器本体は 有効貯湯量2001タイプのメーカーカタログ7かか、配管部 分は2階建てとして延長 $34 \mathrm{~m}$ 想定して材料別重量を求め、 $\mathrm{CO}_{2}$ 排出強度を乗じて推計した（表5参照）。また、年間 集熱量はメーカーによる仙台地域の試算値（4月～11月） である1,204Mcal/年戸を用いた。

戸建て住宅の全て約 1,400 戸に設置した場合の年間集熱 量は約 $1,634 \mathrm{Gcal} /$ 年と推計され、都市ガス消費量削減によ り $\mathrm{CO}_{2}$ 排出量は約118ton/年の排出抑制となる。

太陽熱温水器による $\mathrm{CO}_{2}$ 排出量抑制効果は、未導入の原

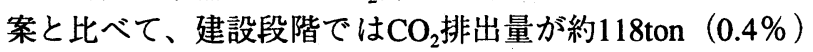
増加するが、運用段階では約 118 ton/年 $(1.9 \%) 、 15$ 年間 を通して約 $1.0 \%$ 抑制できることが把握できた（図8参照）。

太陽熱温水器の設置費用をカタログの材工込み価格 31.8 万円/基とすると、ガス料金の節減による費用回収期間は 約 18 年と耐用年数程度となり、一般的な普及には微妙なと ころにある（図9参照）。

\section{3地域冷暖房システムによる $\mathrm{CO}_{2}$ 排出量の抑制}

通常、地域冷暖房システムは、業務・商業施設の集積に より熱負荷密度の高い地区に導入される。Pニュータウン における、業務・商業施設のピーク時熱負荷は、用途別 熱負荷および月比率・時間比率 ${ }^{8)}$ から推計すると、暖房が $15.7 \mathrm{Gcal} / \mathrm{hr}$ (1月 8時) 、給湯が $2.8 \mathrm{Gcal} / \mathrm{hr}$ （1月13時）、冷 房が $4.2 \mathrm{Gcal} / \mathrm{hr}$ （8月14時）となり、地域冷暖房システム導 入の目安とされている $5 \mathrm{Gcal} / \mathrm{hr}$ に達している。しかし、施 設配置が集中型でないため、熱負荷密度は小さく、地域配 管の面で不利な条件を有している。本研究では、計画時点 の配慮により改善の可能性が生じる余地を含めて検討する。

検討する導入範囲は、地域冷暖房システムの既存事例を 参考に、業務・商業施設の暖房・冷房・給湯および集合住 宅の給湯とした。

地域冷暖房システムに伴う $\mathrm{CO}_{2}$ 排出量の推計は、プラン 卜の熱源機器の選定、地域配管の敷設方法の設定等の条件 次第で大きな差異が生じる余地があるため、計画時点で考 えられうる条件を設定し、明記した。

\section{（1）プラント設備}

地域冷暖房システムのプラントの設定に当たり、実在の
表5 太陽熱温水器の製造時 $\mathrm{CO}_{2}$ 排出量

\begin{tabular}{|l|l|r|r|r|}
\hline 部材 & 材 質 & $\begin{array}{r}\text { 数量 } \\
\mathrm{kg}\end{array}$ & $\begin{array}{l}\mathrm{CO} 2 \text { 強度 } \\
\mathrm{kg}-\mathrm{C} / \mathrm{kg}\end{array}$ & $\begin{array}{l}\mathrm{CO} 2 \text { 排 } \\
\text { 量 } \mathrm{kg}-\mathrm{C}\end{array}$ \\
\hline 集熱板 & SUS444 & 45 & 0.359 & 16.2 \\
\hline 透明板 & ガラス & 9 & 0.516 & 4.6 \\
\hline $\begin{array}{l}\text { 貯 湯 タ } \\
\text { タク }\end{array}$ & $\begin{array}{l}\text { ポリ エ } \\
\text { チレン }\end{array}$ & 30 & 0.521 & 15.6 \\
\hline 保温材 & $\begin{array}{l}\text { ガラ ス } \\
\text { ウール }\end{array}$ & 12 & 0.941 & 11.3 \\
\hline 配管 & 鋼管15A & 45 & 0.890 & 39.6 \\
\hline 合計 & --- & 141 &.-- & 87.4 \\
\hline
\end{tabular}

$$
\text { *眝湯量2001タイプ }
$$

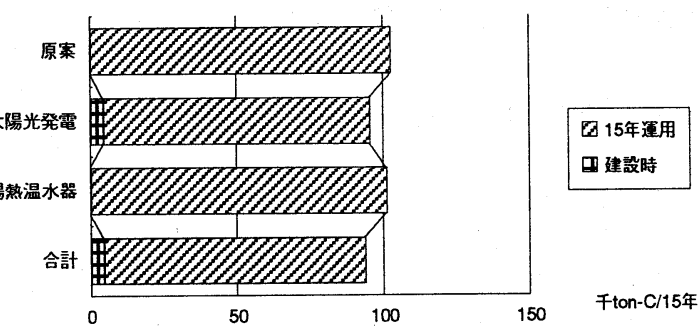

図8 太陽エネルギー関連改善案 $\left(\mathrm{CO}_{2}\right)$

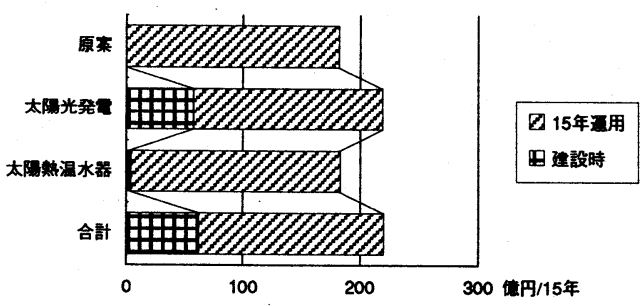

図9 太陽エネルギー関連改善案(金額)

表6 地域冷暖房沉么関連主な $\mathrm{CO}_{2}$ 排出量算定式

\begin{tabular}{|l|l|r|}
\hline 機器名 & $\begin{array}{c}\text { CO2排出量算定式 3) } \\
(\mathrm{kg}-\mathrm{C})\end{array}$ & $\begin{array}{l}\text { 加 工 / 資 } \\
\text { 材比 9) }\end{array}$ \\
\hline 吸収式冷凍機 & $12.79 * \mathrm{X}(\mathrm{USRT})+1828$ & 3.6 \\
\hline ターボ冷凍機 & $10.45 * \mathrm{X}(\mathrm{USRT})+1733$ & 3.6 \\
\hline 蒸気ボイラー & $0.706 * \mathrm{X}(\mathrm{kg} / \mathrm{hr})+1282$ & 2.0 \\
\hline 温水ボイラー & $1.243 * \mathrm{X}(\mathrm{Mcal} / \mathrm{hr})+340$ & 2.0 \\
\hline 配管 $(\mathrm{SGP})$ & $0.89 * \mathrm{X}(\mathrm{kg}$-配管 $)$ & 1.0 \\
\hline
\end{tabular}

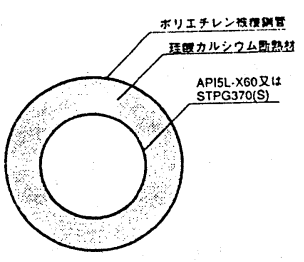

図10地域配管の形状イメージ 
プラントQについて予備検討を行った。造成工事と同様の 手法により解析したが、熱源機器製造の $\mathrm{CO}_{2}$ 排出量は、空 調学会 ${ }^{3)}$ が機器能力または重量から材料の構成量を分析し て求めた簡便式と酒井 ${ }^{9)}$ の設備機器類に関する資材製造段 階と資材加工段階の比を引用して推計した（表6参照）。

プラント Q（能力7,200USRT）では $\mathrm{CO}_{2}$ 排出量は 1,333ton-Cとなり、プラント機器本体部分が $59.7 \%$ 、地域 配管部分が $8.0 \%$ 、建築、電気設備、空調換気設備、給排 水衛生設備等の関連施設部分が $21.6 \%$ 、クレーンや運転調 整部分が10.6\%を占めるとわかった。

$\mathrm{P}$ ニュータウンの地冷プラントの熱源機器は、吸収式冷 凍機とボイラーによる従来型とし、導入対象地区の時間最 大熱負荷に対応する能力を想定した。関連施設部分はプラ ントQを参考に熱量比例とした。この場合、プラント建設 部分のCO2排出量は414ton-Cと推計した（表7参照）。

\section{（2）地域配管}

配管方法は、Pニュータウンでは輸送熱量が少なく比較 的小口径になることから、二重管 (図10参照) を直接埋設 する方式とした（図11参照）。口径別に資材や重機の施工 数量と配管材数量を先行研究 ${ }^{10)}{ }^{11)}$ 参考に設定し、口径 別単位長当たり $\mathrm{CO}_{2}$ 排出量を算定した（図12参照）。

また、口径別地域配管延長については、プラント位置を 業務商業地区に仮定し、ブロック毎の時間最大熱量および 温度差 (冷熱 $7^{\circ} \mathrm{C} 、$ 温熱 $5^{\circ} \mathrm{C}$ ) 、最大流速 $3 \mathrm{~m} / \mathrm{sec}$ 、道路配置 等の条件を考慮して算定した（表7、図14参照）。Pニュー タウンの地域配管による $\mathrm{CO}_{2}$ 排出量は1,302ton-Cとなり、 プラント部分の約 3.1 倍に相当する。

\section{（3）建物側設備}

地域冷暖房システムが予め導入されていれば、各建物で は熱源設備が原則的には不要になる。そのため、比較評価 にあたり、建物建設時のCO2排出量のうち熱源部分を控除 する必要がある。本研究では、業務・商業施設については 先行研究 ${ }^{12)}$ を参考に $3 \mathrm{~kg}-\mathrm{C} / \mathrm{m}^{2}$ を控除し、集合住宅部分は 追炊き機能が求められ得ることから控除しなかった。個別 熱源不要に伴い、 $\mathrm{CO}_{2}$ 排出量は288ton-C抑制が見込める。

\section{（4）地域冷暖房システム建設による $\mathrm{CO}_{2}$ 排出量}

以上の検討により、Pニュータウンに地域冷暖房システ 厶を導入する場合、建設時のCO2排出量は未導入に比べて 1,428ton-C増大することになる。

\section{（5）地域冷暖房システム運用による $\mathrm{CO}_{2}$ 排出量抑制}

導入範囲とした業務・商業施設の暖房・冷房・給湯およ び集合住宅の給湯について、個別熱源の場合と、地域冷暖 房システムの場合のCO2排出量を比較した。熱源機器や地 域配管条件等は検討事例 ${ }^{13)}$ を参考に設定した（表8参照）。

地域冷暖房システムに関わる $\mathrm{CO}_{2}$ 排出量は 1,566 ton- $\mathrm{C} /$ 年 であり、対応する部分の個別システムの場合の1,937ton-C/
表7 $P$ ニュータウン地域冷暖房システムの機器 設定と建設時のCO2排出量

\begin{tabular}{|l|c|r|}
\hline \multicolumn{1}{|c|}{ 項 目 } & 容 量等 & CO2排出量ton-C \\
\hline 吸収式冷凍機 & $1,400 \mathrm{USRT}$ & 71 \\
\hline 温水ボイラー & $17,000 \mathrm{Mcal} / \mathrm{hr}$ & 43 \\
\hline プラント配管 & 132 ton-配管 & 118 \\
\hline 自動制御設備 & 一式 & 28 \\
\hline 建築 & 一式 & 23 \\
\hline 電気設備 & 一式 & 66 \\
\hline 空調換気設備 & 一式 & 41 \\
\hline 給排水衛生設備 & 一式 & 25 \\
\hline プラント小計 & -- & 414 \\
\hline 地域配管 (冷) & $\begin{array}{c}\phi 100-200, \\
\mathrm{~L}=1780 \mathrm{~m}\end{array}$ \\
\hline 地域配管 (温) & $\begin{array}{l}\phi 100-600, \\
\mathrm{~L}=2230 \mathrm{~m}\end{array}$ \\
\hline 地域配管小計 & -- & 232 \\
\hline 地冷施設合計 & - & 1,070 \\
\hline
\end{tabular}

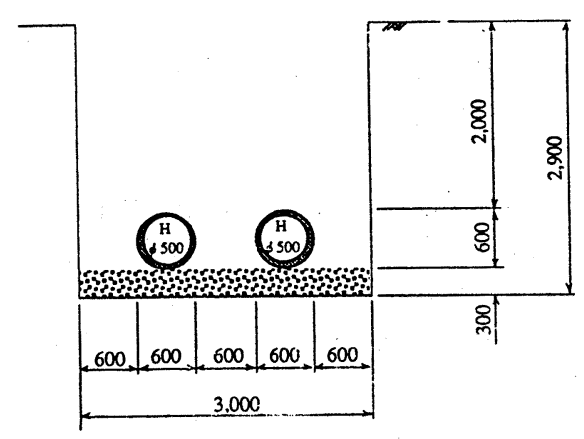

図11 地域配管の敷設条件

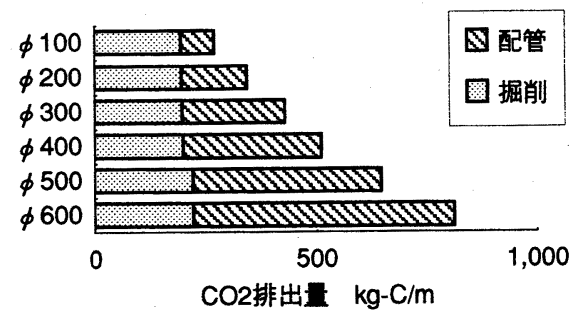

図12 地域配管口径別 $\mathrm{CO}_{2}$ 排出量 
年と比較して、371ton-C/年（19\%）の削減となる。これ は、建設段階のCO2排出量増大分を3.8年で回収することが できことに相当する（図13参照）。地域冷暖房システム整 備が建物建設後になり個別熱源を当面必要とする場合でも 4.6 年で回収できる。

\section{（6）費用面からの導入可能性}

地域冷暖房システムの建設費はプラントQおよび先行研 究 ${ }^{10)}{ }^{11)}$ を参考にすると、プラント部分で約 11 億円、地域 配管部分で約32億円、合計43億円程度と見迄まれる。一方、 燃料単価を単純に全国平均值である都市ガス 14.5 円/Mcal、 電力 24.3 円 $/ \mathrm{kWh}$ とすると、燃料費の節減量は 0.8 億円/年に すぎず、資金回収には50年を必要とする。ただし、燃料費 は厳密には、基本料金と従量料金の組合せであり、また、 ガスの夏期割引料金や電力の特高受電、深夜電力料金等の 料金体系の複雑さがある。さらに、通常は、地域熱供給事 業はエネルギー供給会社等を主体にした地域冷暖房会社が 行い、ニュータウン全体の開発事業者とは別組織である。 地冷会社の事業収支構造は、プラントや地域配管を先行投 資で建設し、熱販売による収入を得て、燃料費、保守管理 費等を賄い、借入金を返済していくため、金利負担を考慮 するとPニュータウンでの事業採算性は成立しない。しか し、 $\mathrm{CO}_{2}$ 排出量抑制には有効であり、施設毎に後から導入 できないインフラ施設であるため、予め地区として整備す るのであれば、公共投資の導入等の支援方策が望まれる。

\section{4地域冷暖房汉行に対応した土地利用計画の変更}

$\mathrm{P}$ ニュータウンへの地域冷暖房システムの導入が困難な 理由は、地域配管の建設費負担が過大なためであった。そ こで、原案の土地利用フレームは維持したまま、業務・商 業施設を集約配置することにより、地域配管延長を削減す る代替案を検討した（図14参照）。具体的には、プラント 想定地に近い戸建住宅地と離れている業務施設の配置を入 れ換えた場合を検討した。幹線道路沿いに戸建住宅地を配 置することによる道路公害の危惧はあるものの、ニュー夕 ウン全体の道路パターンや造成計画に影響は少ないと考え られる。

この場合、配管延長は約 $600 \mathrm{~m}$ 削減され、建設時のCO2排 出量は240ton-C抑制される。また、延長減少により搬送動 力負荷と熱損失も小さくなり、運用時には16ton-C/年抑制 される。建設費の低減等にともない、建設資金回収に必要 な期間は41年と若干短縮されるが、事業採算的にはやは り成立困難である。地域冷暖房システムの事業化のため には、配置計画の見直しのみでは不十分であり、密度向 上等の対応を併せて行う必要がある。

\section{5.各 $\mathrm{CO}_{2}$ 排出量抑制方法の比較評価}

$\mathrm{P}$ ニュータウンに以上の各方法を導入した場合の建設・ 運用時を通じて供用開始後15年間について、 $\mathrm{CO}_{2}$ 排出抑制 量、費用、その他の面から比較評価した。（表9、図16参
表8 熱源機器等の主な設定条件

\begin{tabular}{|l|l|}
\hline 機器名称 & 設定条件 \\
\hline 吸収式冷凍機 & 沉 4 COP 0.6 \\
\hline 二重効用吸収式冷凍機 & 沉 4 COP 1.1 \\
\hline ボイラー (地冷) & 効率 0.8 \\
\hline ボイラー (個別) & 効率 0.6 \\
\hline ガス湯沸かし器 & 効率 0.72 \\
\hline 地域配管熱ロス & 熱輸送効率95\% \\
\hline 地域配管搬送動力 & ポンプ効率 $60 \%$ \\
\hline
\end{tabular}

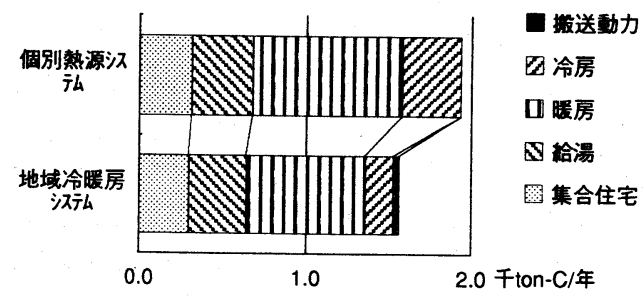

図13地域冷暖房システムによる $\mathrm{CO}_{2}$ 排出量 の比較（供用時1年間）

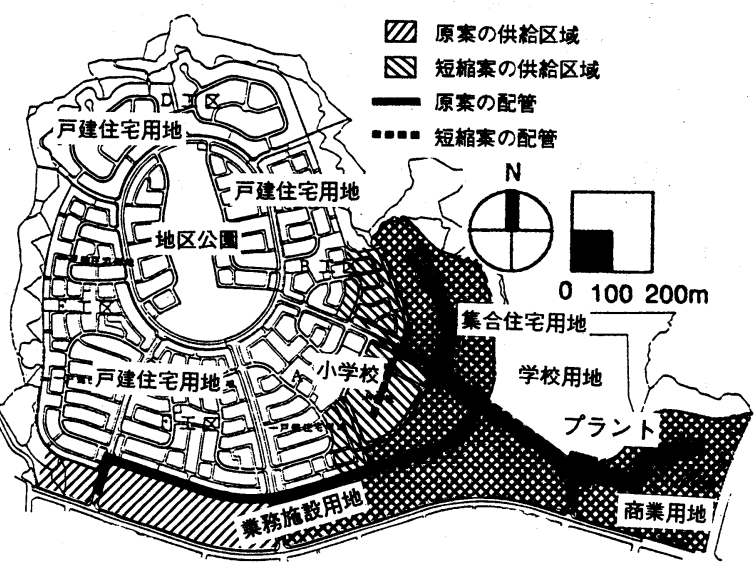

図14 Pニュータウン地域配管ルート想定

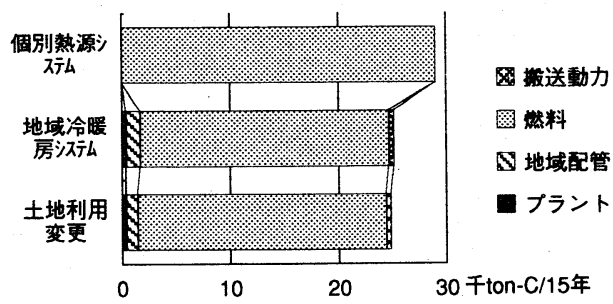

図15地域冷暖房システ公等によるCO2排出 量の比較（建設および共用後15年間） 
照）。削減効果が小さいが導入は容易な擁壁の法面化、歩 道の仕様変更等と、逆に、削減効果が大きいが費用面で導 入が困難な太陽光発電システム、地域冷暖房システムといっ

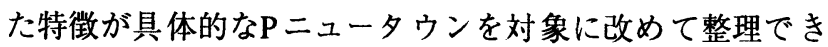
た（図16参照）。

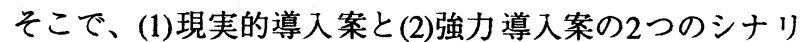
オを検討した。(1)単純に経済的な面から導入しやすい造成 関連および太陽熱利用システムを導入する現実的導入案で は15年を通して $\mathrm{CO}_{2}$ 排出量を約 4.8 千 ton-C (2.9\%) 抑制で き、(2)さらに政策的に強力に太陽光発電システムと地域冷 暖房システムを付加する強力導入案では約 15.0 千 ton-C （8.9\%）抑制可能と把握できた（図17参照）。

参考に我が国での実施は不透明だが、欧州では導入され つつある環境税（炭素税）が課税された場合に、経済的イ ンセンティブになりうるかを検討した。環境税はエネルギー 関連税制全体の中で課税時点や方法等を検討されるべきで あるが、上流側の化石燃料に課税され、社会経済的な間接 影響は考えずに単純化して比較した。例えばスウェーデン の 18.8 円 $/ \mathrm{kg}-\mathrm{C}$ と同水準の環境税の場合には、太陽光発電シ ステムや地域冷暖房システムの $\mathrm{CO}_{2}$ 抑制単価510～720円 $/ \mathrm{kg}$-Cと比べて小さく、環境税のみでは太陽光発電システ ムや地域冷暖房システムを導入するインセンティブになら ないとわかった。

抑制効果が大きいが費用面で導入が困難な太陽光発電システムや地域冷暖房システム等を普及させるた めには、機器効率の向上およびコストダウンに加えて、環境税を財源とした助成策をうまく組み合わせる ことが重要になる。

\section{表9 各CO2排出量抑制方法の比較評価}

\begin{tabular}{|c|c|c|c|c|c|c|c|c|c|c|}
\hline \multirow{2}{*}{ 項 目 } & \multicolumn{3}{|c|}{$\mathrm{CO}_{2}$ 排出量 単位: ton-C } & \multicolumn{2}{|l|}{ 金額 } & 単位 : 億円 & \multicolumn{2}{|c|}{ 回収年数 } & \multirow{2}{*}{$\begin{array}{l}\text { 参考耐 } \\
\text { 用年数 }\end{array}$} & \multirow{2}{*}{$\begin{array}{l}\mathrm{CO} 2 \text { 排出抑 } \\
\text { 制単価 } \\
\text { 千开 } / \mathrm{kg}-\mathrm{C}\end{array}$} \\
\hline & $\begin{array}{l}\text { 建 設 時 } \\
\text { 増滅量 }\end{array}$ & $\begin{array}{l}\text { 供用時 } \\
\text { 増減量 }\end{array}$ & $\begin{array}{l}\text { 15年累計 } \\
\text { 増減量 }\end{array}$ & $\begin{array}{l}\text { 建設時 } \\
\text { 増减量 }\end{array}$ & $\begin{array}{l}\text { 供用時 } \\
\text { 増減量 }\end{array}$ & $\begin{array}{l}15 \text { 年 累計 } \\
\text { 増減額 }\end{array}$ & $\mathrm{CO}_{2}$ & 金額 & & \\
\hline 1-1ブロック擁壁の法面化 & $-1,900$ & 0 & $-1,900$ & -10.5 & 0.0 & -10.5 & 0.0 & 0.0 & 15 & -0.55 \\
\hline 1-2RC擁壁の法面化 & -226 & 0 & -226 & -1.6 & 0.0 & -1.6 & 0.0 & 0.0 & 15 & -0.70 \\
\hline 1-3歩道の舗装の変更 & -925 & 0 & -925 & -4.4 & 0.0 & -4.4 & 0.0 & 0.0 & 20 & -0.47 \\
\hline 1-4公園の仕様変更 & -142 & 0 & -142 & -2.4 & 0.0 & -2.4 & 0.0 & 0.0 & $15 \sim 20$ & -1.69 \\
\hline 2-1太陽光発電汣彶 & 4,355 & -778 & $-7,318$ & 57.4 & -1.4 & 37.0 & 5.6 & 42.2 & 15 & 0.51 \\
\hline 2-2太陽熱温水器 & 118 & -118 & $-1,652$ & 4.3 & -0.2 & 0.7 & 1.0 & 17.7 & 15 & 0.04 \\
\hline 3-1地域冷暖房㳅 & 1,716 & -371 & $-3,853$ & 39.9 & -0.8 & 27.9 & 4.6 & 49.9 & $15 \sim 20$ & 0.72 \\
\hline 3-2土地利用計画変更 & 1,476 & -387 & $-4,336$ & 33.7 & -0.8 & 21.3 & 3.8 & 40.6 & $15 \sim 20$ & 0.49 \\
\hline
\end{tabular}

参考）原案 $\mathrm{CO}_{2}$ 排出量 建設時：約70.9千ton-C、供用時：約6.2千ton-C/年、15年累計：約164.2千ton/15年 


\section{6.まとめ}

本研究では、具体的なニュータウンを対象に現実的な設計見直しを行った上で、計画時点で扱える情報か ら、ライフサイクルを通じた $\mathrm{CO}_{2}$ 排出量抑制効果を定量的に推計し、排出構造をインベントリー分析するこ とにより、次のことが明らかになった。

1）面積 $162 \mathrm{ha} 、$ 人口 9,600 人のニュータウンの造成工事に起因する $\mathrm{CO}_{2}$ 排出量は、物量を主に金額で補足す る改良した推計方法によると約27.2千ton-Cとなり、金額のみによる推計と比べて15\%の差異があった。

2）造成工事関連の $\mathrm{CO}_{2}$ 排出量の抑制方法は、擁壁等のコンクリート構造物の法面化による代替、公園の遊 戯施設の整備コンセプトや仕様の変更等を検討した。これらにより、造成工事からのCO \%抑制することが期待できる。これらの対応方法は、抑制効果は小さいながら、費用も低減するため導 入余地があると考えられる。しかし、一方で、アメニティ面等を含めた十分な検討が必要となる。

3）低密度な郊外型ニュータウンに個別に適用可能な $\mathrm{CO}_{2}$ 排出量抑制技術には、太陽光発電システム、太陽 熱利用システムがある。これらにより、建設および供用後 15 年間を通した $\mathrm{CO}_{2}$ 排出量の $5.5 \%$ 程度の抑制 が期待できる。しかし、宮城県では現状のシステム価格と効率では一般的な普及には不十分である。

4）通常は高密度開発地区で導入される地域冷暖房システムは、低密度地区の場合には地域配管部分の負荷 ·

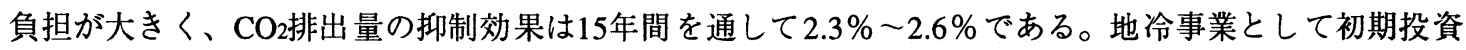
を回収することは困難なため、高密度開発化による地域配管延長の一層の短縮や、公的支援が期待され る。

5）欧州では導入されつつある環境税（炭素税）の課税のみでは、太陽光発電システムや地域冷暖房システ ム等を導入するインセンティブとはならない。それらの普及にはコストダウンと機器効率の向上、環境 税を財源とした助成策の組合せが重要とわかった。

今後の検討課題として、次の 2 点が挙げられる。造成工事の中で最大のCO2排出項目である整地工事を減 少するために、戸建て住宅を集合住宅に変更する等の土地利用計画の検討、および、CO2排出量抑制に寄与 する未利用エネルギーの活用可能性を含めて都市環境システムとして備えるべき技術の検討が必要である。 ただし、各 $\mathrm{CO}_{2}$ 排出量抑制技術についてアメニティ面やライフスタイル面も加味して比較することが重要で ある。

研究にあたり、 $\mathrm{P}$ ニュータウンの施工関連資料を提供いただいた大成建設（株）東北支店菅野俊則氏、お よびに、同・開発本部の谷内康弘氏に謝意を表します。

\section{参考文献}

1）伊藤武美・花木啓祐・谷口孚幸・有浦幸隆（1995）：ニュータウン建設にともなう二酸化炭素排出量に関する研 究、環境システム研究vol.23、p190-197

2）省資源・省エネルギー型国土建設技術に関する調查建築委員会（1994）：省資源・省エネルギー型国土建設技術 の開発 (建築委員会) 報告書、(財)国土開発技術研究センター、P16-18·P31-36

3）(社) 空気調和・衛生工学会地球環境に関する委員会（1995）：地球環境時代における建筑設備の課題、p73-79、 P123-133

4）伊藤武美・花木啓祐・本多博（1996）：公園建設にともなう二酸化炭素排出量に関する研究、第4回地球環境シン ポジウム講演集、p63-68

5）三洋ソーラーエナジーシステム（株）他（1993）：個人住宅用太陽光発電システムカタログ

6) 稲葉敦・島谷哲 他 (1994）：太陽光発電システムのエネルギー評価、化学工学論文集第19巻第5号、p809-817

7）朝日ソーラー（株）（1995）：自然循環型太陽温水器カタログ

8) 大成建設 (株) 技術研究所 (1988) : コ・ジェネレーションシステム評価用調查研究報告書、p $21-26$

9）酒井寬二（1995）：建築活動と地球環境-建築のライフサイクル環境評価-、空気調和・衛生工学会新書、p133

10）廣川澄子・仙石芳英・新田勝広（1994）：広域熱供給事業における配管敷設費の低減に関する一考察、土木学会 第49回年次学術講演会概要集4、p470-471

11）北電興業（株）（1994）：札幌広域熱供給ネットワーク構想における熱輸送システム調査

12）石黒邦道・石福昭・佐川佑一郎他（1995）：LCCO2による事務所ビルの環境負荷の試算、空気調和・衛生工学会 学術講演会講演論文集、p1325-1328

13）電力中央研究所・大成建設（1993）：環境共生・省工ネ都市の研究 